\title{
招待講演
}

注）＃印は日本心理学会会員以外であることを示す。

第1日 9 月10日 (水)

$9: 20 \sim 10: 50$

RY206

\section{SL-001 Emotion is in the eye of the interpreter. What matters is not where you take it from, but where you take it}

\author{
講演者：Debi Roberson (University of Essex) \\ 司会者：菊谷まり子\# (同志社大学)
}

Over the last half-century, many hundreds of studies have investigated the nature of facial expressions of emotion. Some researchers have suggested that a small, fixed set of emotional expressions, such as anger, fear, and sadness, are universally produced and/or recognized in all communities and might also be innately determined. Others have proposed that there are profound cultural differences between communities, especially between 'Oriental' and 'Occidental" perceivers because some cultures encourage individuals to conceptualize emotions as located within themselves, whereas other cultures tend to conceptualize emotion as reflecting relationships between people. The latter view takes more account of the context in which facial expressions are produced and interpreted.

I will argue that emotion interpretation is an intensely interactive process that must be studied as such. This is because, unlike for more concrete perceptual categories, emotions (and the facial expressions that show them) change in predictable ways in response to the perceiver. Take, for instance, a smiling face, that represents happiness. If the perceiver, instead of smiling, frowns - then the smile is likely to fade rapidly. In the case of a fearful expression, a mirrored movement of micromuscles will lead to a spiralling increase in fear levels. If we are to understand more about the processes involved in interpreting facial expressions of emotion, more effort needs to be directed towards the context in which they are expressed.

Academic Profile and Publications: http://www.essex.ac.uk/psychology/staff/profile.aspx?ID=2436 